\title{
Isotype-specific inhibition of the phosphatidylinositol-3-kinase pathway in hematologic malignancies
}

This article was published in the following Dove Press journal:

OncoTargets and Therapy

2I February 2014

Number of times this article has been viewed

Jorge J Castillo'

Meera lyengar ${ }^{2}$

Benjamin Kuritzky²

Kenneth D Bishop ${ }^{2}$

'Division of Hematologic Malignancies, Dana-Farber Cancer Institute, Boston, MA, ${ }^{2}$ Division of Hematology and Oncology, Rhode Island Hospital, Providence, RI, USA
Correspondence: Jorge J Castillo

450 Brookline Ave, M22I,

Boston, MA 02215, USA

$\mathrm{Tel}+\mathrm{I} 6176326285$

Fax +I 6176326482

Email jorgej_castillo@dfci.harvard.edu
Abstract: In the last decade, the advent of biological targeted therapies has revolutionized the management of several types of cancer, especially in the realm of hematologic malignancies. One of these pathways, and the center of this review, is the phosphatidylinositol-3-kinase (PI3K) pathway. The PI3K pathway seems to play an important role in the pathogenesis and survival advantage in hematologic malignancies, such as leukemia, lymphoma, and myeloma. The objectives of the present review, hence, are to describe the current knowledge on the PI3K pathway and its isoforms, and to summarize preclinical and clinical studies using PI3K inhibitors, focusing on the advances made in hematologic malignancies.

Keywords: phosphatidylinositol-3-kinase pathway, inhibitors, leukemia, lymphoma, myeloma

\section{Introduction}

In the last decade, the advent of biological targeted therapies has revolutionized the management of several types of cancer, especially in the realm of hematologic malignancies. For example, monoclonal antibody therapy has been shown to increase response and survival rates in patients with non-Hodgkin and Hodgkin lymphoma and chronic lymphocytic leukemia. Furthermore, orally administered small molecules have become the mainstay of treatment for plasma cell myeloma and chronic myeloid leukemia.

The reasons for these advancements are several, but the main driver has been the increased and improved understanding of the multiplicity of intracellular pathways that could be affected during the oncogenic process, providing cancer cells with a wide variety of mechanisms by which to thrive, survive, and multiply. One of these pathways, and the center of this review, is the phosphatidylinositol-3-kinase (PI3K) pathway. The PI3K pathway seems to play an important role in the pathogenesis and survival advantage in hematologic malignancies, such as leukemia, lymphoma, and myeloma. For this purpose, a series of PI3K inhibitors are in ongoing preclinical and clinical development with enthusiasm for the treatment of these conditions.

The objectives of the present review are to describe the current knowledge of the PI3K pathway and its isoforms, and to summarize ongoing preclinical and clinical studies using PI3K inhibitors, focusing on the advances made in hematologic malignancies.

\section{PI3K pathway}

PI3K forms part of the PI3K/acutely transforming retrovirus (AKT)/mammalian target of rapamycin (mTOR) pathway, which is a complex cascade of signal transduction 
that regulates proliferation and intracellular metabolism, as well as cell survival, differentiation, motility, and migration (Figure 1). The PI3K/AKT/mTOR pathway has been associated not only with normal hematopoiesis but also with the development and maintenance of a number of malignancies. There are three classes of PI3K described, ie, class I, II, and III.

Class I PI3K has been associated with oncogenesis. ${ }^{1}$ PI3K is a heterodimer formed by two subunits, one catalytic and one regulatory. The catalytic subunit, p110, has four isotypes, ie, alpha, beta, gamma, and delta, encoded by the genes $P I K 3 C A, P I K 3 C B, P I K 3 C G$, and $P I K 3 C D$, respectively. ${ }^{2}$ The $\mathrm{p} 110$-alpha isotype has a role in insulindependent signaling, p110-beta in platelet aggregation, thrombosis, and insulin signaling, and p110-gamma and delta are expressed mainly in leukocytes and have roles in lymphocyte activation, mast cell degranulation, and chemotaxis. ${ }^{3}$ The catalytic p110 subunit associates with one of three p85-related regulatory subunits, p85-alpha, p85-beta, and p55-gamma, which are encoded by the genes PIK3R1, PIK3R2, and PIK3R3, respectively. ${ }^{2}$ The $\mathrm{p} 85$ regulatory subunit is activated via receptor tyrosine kinase stimulation by binding to phosphotyrosine residues in the receptor tyrosine kinase. Such a process relieves the catalytic p110 subunit from the inhibition of the regulatory p85 subunit. PI3K then localizes in the cellular membrane where the subunit p110 converts phosphatidylinositol $(4,5)$-bisphosphate into phosphatidylinositol $(3,4,5)$-triphosphate, which then activates downstream AKT with participation of 3-phosphoinositide-dependent protein kinase-1 (PDK1), PDK2, and mTOR-rictor. AKT, a serine/threonine kinase, in turn modulates the activity of mTORC1, BCL-2 (BAD), FOXO, p53, p27, C-MYC, insulin-like growth factors, and cyclin D1, resulting in dysregulation of metabolism and protein synthesis, and cell growth, proliferation, and survival. ${ }^{4}$

There are three isoforms of class II PI3Ks, ie, PI3KC2-alpha, PI3KC2-beta, and PI3KC2-gamma. However, no regulatory subunits have been described for these enzymes. PI3KC2-alpha seems to have a role in clathrin-mediated vesicle trafficking, neurosecretory granular exocytosis, smooth muscle contraction, and insulin signaling, and PI3KC2-beta in cell migration and neuronal cell survival. ${ }^{3}$ The function of PI3KC2 has not yet been determined. Class III PI3K, also known as vacuolar protein sorting 34 , is encoded by the $P I 3 K C 3$ gene, and associates with the putative serine/ threonine protein tyrosine kinase p150 regulatory subunit. Vacuolar protein sorting 34 has a role in vesicular trafficking of membrane proteins to the lysosome, and has also been implicated in activation of the mTOR pathway. ${ }^{3}$

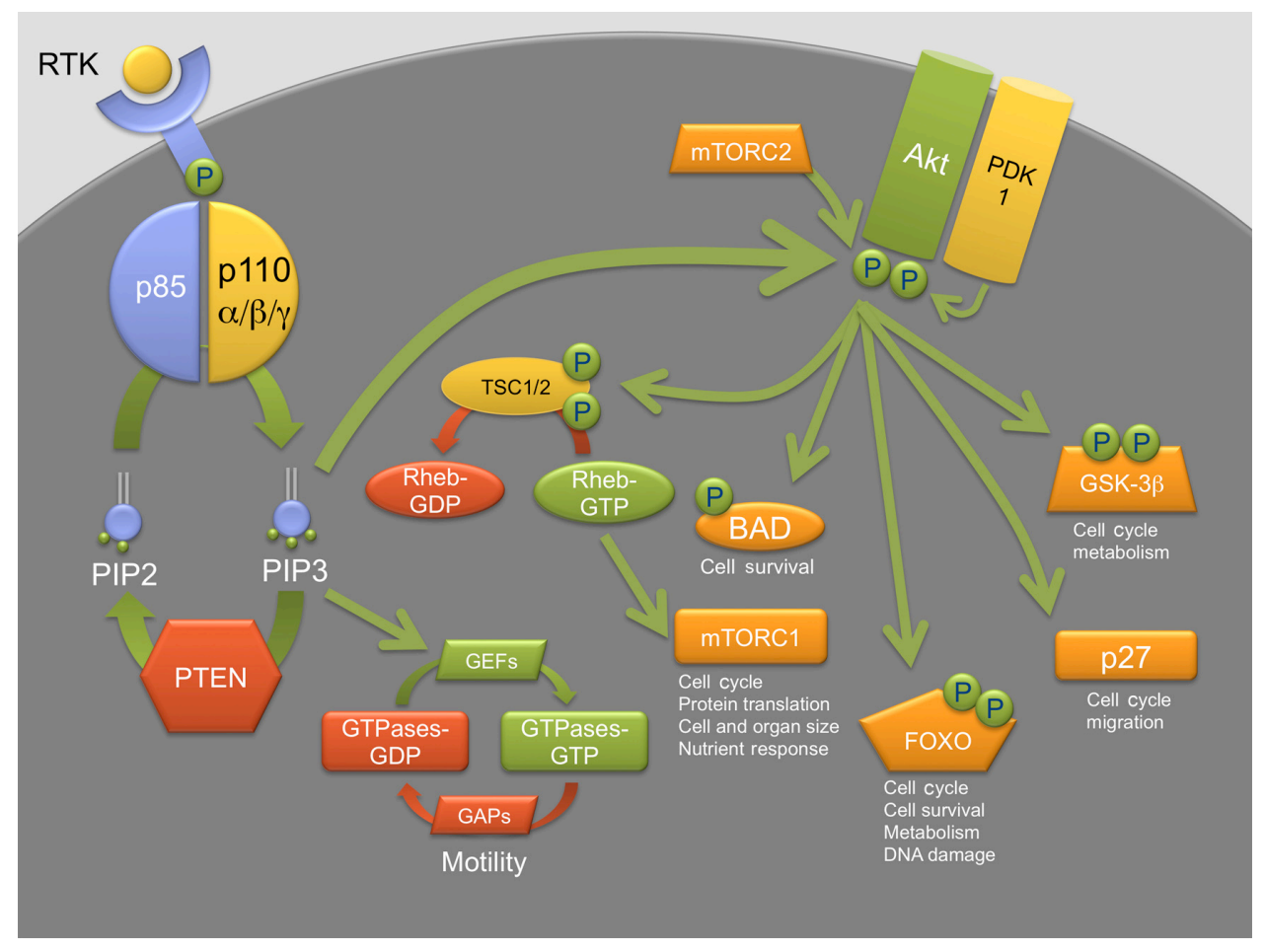

Figure I PI3K/AKT/mTOR pathway.

Abbreviations: PI3K, phosphatidylinositol-3-kinase; AKT, protein kinase B; mTOR, mammalian target of rapamycin. 


\section{PI3K pathway targeting in hematologic malignancies}

The PI3K p110-delta isotype plays a critical role in the signaling pathways of various types of leukemia. Hence, it has become an attractive target for pharmacotherapy. While other isoforms of class I PI3K molecules (ie, p110-alpha and p110-beta) are expressed ubiquitously in mammalian tissue, the p110-delta subunit appears to be more selectively expressed in leukocytes. ${ }^{5}$ Preclinical data on acute myeloid leukemia and chronic lymphocytic leukemia has identified the p110-delta subunit as a predominant isoform in these diseases. ${ }^{6,7}$ Sujobert et al showed consistently increased activity of p110-delta, in contrast with p110-alpha and p110-beta, in leukemic blasts from patients with a diagnosis of acute myeloid leukemia who participated in clinical trials by the "Groupe Ouest-Est des Leucémies et des Autres Maladies du Sang". ' Similarly, Herman et al showed increased activity of p110-delta in cells from patients with chronic lymphocytic leukemia. Additionally, constitutive activation of p110-delta was significantly higher in malignant cells when compared with normal B-cells from the same patients. ${ }^{6}$

In 2000, Borlado et al developed a mouse model in which increased activity of PI3K was associated with development of infiltrating malignant lymphomatous lesions. ${ }^{8}$ Since then, a number of studies have focused on evaluating the pathophysiologic role played by the PI3K pathway in lymphoma. Uddin et al demonstrated that the PI3K pathway was constitutively active in diffuse large B-cell lymphoma (DLBCL) cell lines and primary cells from DLBCL patients. ${ }^{9} \mathrm{PI} 3 \mathrm{~K}$ activity, reflected by AKT phosphorylation, was identified in $52 \%$ of primary DLBCL cells. Interestingly, AKT-activated DLBCL patients had a worse 5-year overall survival rate. In the same experiment, inhibition of the PI3K pathway induced apoptosis in DLBCL cells. A retrospective study has also shown that AKT-activated DLBCL patients have worse outcomes even when treated with a rituximab-containing regimen. ${ }^{10}$ Rudelius et al investigated the activity of the PI3K pathway in mantle cell lymphoma, and showed constitutive activation in mantle cell lymphoma cell lines and also in primary cells derived from patients with blastoid (100\% of cases) and typical mantle cell lymphoma ( $30 \%$ of cases), measured by activated AKT. ${ }^{11}$ Blastoid mantle cell lymphoma, although rare, is a hard-totreat lymphoma with extremely poor outcomes. PI3K pathway activation has also been demonstrated in follicular lymphoma and Hodgkin lymphoma cell lines. ${ }^{12,13}$

The PI3K pathway also seems of importance in plasma cell myeloma. Ikeda et al showed that p110-delta, the catalytic portion of PI3K, was overactive not only in plasma cell myeloma cell lines but also in the malignant cells of 24 patients with a diagnosis of plasma cell myeloma. ${ }^{14}$

Based on the results of these experiments, the clinical use of p110-delta isotype-specific inhibitors of the PI3K pathway is of interest and specific molecules targeted at p110-delta could become an additional weapon in our armamentarium against specific types of leukemia, lymphoma, and myeloma. The isotype-specific effects of selected PI3K inhibitors are shown in Table 1.

\section{Idelalisib (GS- I I 0 I , CAL- I 0 I)}

Idelalisib is a highly specific inhibitor of the PI3K p110-delta subunit that has oral bioavailability. Idelalisib is a PI3K inhibitor that is more advanced in its clinical development, and has been studied in leukemia, lymphoma, and myeloma.

\section{Preclinical data}

In vitro studies using idelalisib in chronic lymphocytic leukemia and acute myeloid leukemia have shown promising activity in terms of inhibiting constitutively active oncogenic stimuli, inducing apoptosis, and blocking survival signaling from the microenvironment while minimally impacting normal hematopoietic cells. ${ }^{6}, 15$ Additional in vitro studies in chronic lymphocytic leukemia cell lines have shown that idelalisib-treated cells have inhibited chemotaxis, downregulation of chemokines, and impaired susceptibility to cell survival signals. ${ }^{16}$ Furthermore, it has been shown that treatment with idelalisib can sensitize chronic lymphocytic leukemia cells to chemotherapy. Data from Herman et al have shown a beneficial effect of combination therapy with idelalisib and the immunomodulator lenalidomide. ${ }^{17}$ Lenalidomide has been associated with a cytokine release syndrome when given in chronic lymphocytic leukemia, which is thought to be

Table I Biochemical profile of selected PI3K inhibitors against class I, II, and III PI3Ks (IC ${ }_{50}$ levels in $\left.\mathrm{nM}\right)$

\begin{tabular}{|c|c|c|c|c|c|c|}
\hline \multirow[t]{2}{*}{ Inhibitor } & \multicolumn{4}{|c|}{ Class I } & \multirow[t]{2}{*}{ Class II } & \multirow[t]{2}{*}{ Class III } \\
\hline & $\begin{array}{l}\text { pII0- } \\
\text { alpha }\end{array}$ & $\begin{array}{l}\text { pII0- } \\
\text { beta }\end{array}$ & $\begin{array}{l}\text { pIlo- } \\
\text { gamma }\end{array}$ & $\begin{array}{l}\text { pIlo- } \\
\text { delta }\end{array}$ & & \\
\hline Idelalisib & 820 & 565 & 89 & 2.5 & $>10^{3}$ & 978 \\
\hline AMG 319 & - & - & - & $<10$ & - & - \\
\hline BAG956 & 56 & 446 & 117 & 35 & - & - \\
\hline BEZ235 & 4 & 75 & 5 & 7 & - & - \\
\hline BGT226 & 4 & 63 & - & 38 & - & - \\
\hline BKMI 20 & 52 & 166 & 262 & 116 & - & 2,410 \\
\hline IC87|I4 & 1,820 & $>1,000$ & 1,240 & 70 & - & - \\
\hline IPII 45 & 1,602 & 85 & 27 & 2.5 & - & - \\
\hline PII03 & 2 & 3 & 15 & 3 & - & - \\
\hline
\end{tabular}

Note: A dash means data are not available.

Abbreviations: $\mathrm{IC}_{50}$, half maximal inhibitory concentration; PI3K, phosphatidylinositol3-kinase. 
due to upregulation of p110-delta and subsequent activation of AKT. ${ }^{18}$ When lenalidomide is given in conjunction with idelalisib, there is less upregulation of cellular prosurvival mediators like phosphorylated AKT, suggesting that concomitant administration of these drugs may produce a dampened immune response while still providing cytotoxicity.

Idelalisib has shown preclinical activity against a number of lymphoma cell lines. Idelalisib downregulated AKT phosphorylation in DLBCL, mantle cell lymphoma, and follicular lymphoma cell lines, and induced a several-fold increase in levels of apoptotic markers, such as caspase 3 and poly-(ADP-ribose) polymerase cleavage. ${ }^{15}$ Meadows et al evaluated the effect of idelalisib in Hodgkin lymphoma cell lines. ${ }^{19}$ High levels of p110-delta and phosphorylated AKT were found in five of five (100\%) Hodgkin lymphoma cell lines investigated. Exposure to idelalisib not only decreased levels of p110-delta and phosphorylated AKT but also disrupted tumor microenvironment-mediated survival signals mediated by CCL5, CCL17, and CCL22 in cocultures of Hodgkin lymphoma cells and bone marrow stem cells. Idelalisib also induced dose-dependent apoptosis of Hodgkin lymphoma cells at 48 hours. Reduced cell viability and increased apoptosis were observed when combining idelalisib with the mTOR inhibitor everolimus.

When idelalisib was tested against plasma cell myeloma cell lines and primary cells, the drug exhibited potency against cells that expressed p110-delta. ${ }^{14}$ Peripheral blood mononuclear cells from healthy donors were not significantly affected by idelalisib. In order to mimic the bone marrow microenvironment, which is thought to be protective for malignant cells in plasma cell myeloma, bone marrow stem cells, interleukin-6, and insulin-like growth factor-1 were added to plasma cell myeloma cells in culture but these did not provide protection against idelalisib-induced apoptosis and cell death. The authors also hypothesized that idelalisib would have antiangiogenesis activity; the drug was tested on human umbilical vein endothelial cells to assess for inhibition of capillary-like tube formation. Idelalisib inhibited capillary-like tube formation in a dose-independent and time-dependent manner. ${ }^{14}$ Additionally, idelalisib showed a synergistic effect when combined with the proteasome inhibitor bortezomib and tested against two of the cell lines that had previously been shown to express p110-delta. ${ }^{14}$

\section{Clinical data}

A series of Phase I/II studies are currently available in abstract form. Not surprisingly, these studies are focused mainly on the treatment of patients with relapsed or refractory hematologic malignancies, although a few studies are already looking at combination therapy in untreated patients. Selected Phase I/II studies using idelalisib either alone or in combination are shown in Table 2. Single-agent idelalisib studies in patients with chronic lymphocytic leukemia, indolent nonHodgkin lymphoma, and mantle cell lymphoma have shown overall response and complete remission rates in the range of $40 \%-50 \%$ and $2 \%-5 \%$, respectively. The response rates for idelalisib in combination with chemotherapy are expectedly higher, with overall response and complete remission rates in the range of $80 \%-100 \%$ and $30 \%-50 \%$, respectively. The most common grade 3 or higher adverse events associated with idelalisib have been pneumonia, diarrhea, and liver enzyme elevation. The design of the four Phase III studies has been reported in abstract form at the 2013 American Society of Clinical Oncology annual scientific meeting (Table 3).

\section{Other PI3K p I I0-delta inhibitors AMG 319}

AMG 319 is a highly selective inhibitor of PI3K p110-delta and has oral bioavailability. In a preclinical study evaluating more than 20 B-cell malignancy cell lines, AMG 319 was found to be a potent inhibitor of AKT activation and effective at reducing the number of viable cells. ${ }^{20}$ However, different cell lines had variable responses to this drug. Further analysis showed that when AMG 319 was given concomitantly with vincristine in vitro and in vivo using a xenograft model of DLBCL, a synergistic effect was noted and there was increased cytotoxicity. ${ }^{21}$ A recent study evaluated AMG 319 alone or in combination with a series of monoclonal antibodies, targeted agents, and chemotherapy drugs in a panel of rituximab-sensitive and rituximab-resistant lymphoma cell lines as well as primary cells from patients with B-cell and T-cell lymphomas. AMG 319 showed dose-dependent activity against all cell lines. Additionally, AMG 319 induced cell death in primary cells at lower doses than in cell lines. Also, pre-exposure to AMG 319 increased the biological activity of rituximab and ofatumumab in terms of antibodydependent and complement-dependent cytotoxicity. The apoptotic mechanism of AMG 319 seems to be mediated via the mitochondrial pathway. Ongoing clinical studies are shown in Table 4.

\section{IC87II 4}

IC87114 is another selective inhibitor of PI3K p110-delta. IC87114 was shown to inhibit proliferation of acute myeloid leukemia blast cells without significant toxicity to normal hematopoietic cells in vitro. ${ }^{7,22}$ In acute myeloid leukemia 
Table 2 Selected clinical trials using idelalisib with data reported at the 2013 American Society of Clinical Oncology annual scientific meeting

\begin{tabular}{|c|c|c|c|c|c|c|}
\hline Author & Phase & Disease & $\mathbf{n}$ & Alone/combination & Outcome & Toxicity (> Grade 3) \\
\hline $\begin{array}{l}\text { Brown } \\
\text { et al }{ }^{44}\end{array}$ & I & $\begin{array}{l}\text { Relapsed } \\
\text { or refractory } \\
\text { CLL }\end{array}$ & 54 & Alone & $\begin{array}{l}\text { ORR } 56 \% \\
\text { CR } 4 \% \\
\text { Median PFS } 17 \text { months }\end{array}$ & $\begin{array}{l}\text { Pneumonia } 19 \% \\
\text { Diarrhea } 6 \% \\
\text { Fever } 4 \%\end{array}$ \\
\hline $\begin{array}{l}\text { Barrientos } \\
\text { et } \mathrm{al}^{45}\end{array}$ & I & $\begin{array}{l}\text { Relapsed } \\
\text { or refractory } \\
\text { CLL }\end{array}$ & 52 & $\begin{array}{l}\text { In combination with rituximab } \\
\text { and/or bendamustine }\end{array}$ & $\begin{array}{l}\text { ORR } 81 \% \\
\text { CR } 2 \% \\
\text { 2-year PFS } 62 \%\end{array}$ & $\begin{array}{l}\text { Diarrhea I4\% } \\
\text { Pneumonia I } 2 \% \\
\text { AST/ALT elevation } 10 \%\end{array}$ \\
\hline $\begin{array}{l}\text { Benson } \\
\text { et }\left.\mathrm{a}\right|^{46}\end{array}$ & I & $\begin{array}{l}\text { Relapsed } \\
\text { or refractory } \\
\text { indolent } \mathrm{NHL}\end{array}$ & 64 & Alone & $\begin{array}{l}\text { ORR } 48 \% \\
\text { CR } 2 \% \\
\text { Median PFS } 8 \text { months }\end{array}$ & $\begin{array}{l}\text { ALT/AST elevation } 25 \% \\
\text { Pneumonia } 16 \% \\
\text { Diarrhea } 8 \%\end{array}$ \\
\hline $\begin{array}{l}\text { Leonard } \\
\text { et } \mathrm{al}^{47}\end{array}$ & 1 & $\begin{array}{l}\text { Relapsed } \\
\text { or refractory } \\
\text { indolent } \mathrm{NHL}\end{array}$ & 78 & $\begin{array}{l}\text { In combination with rituximab } \\
\text { and/or bendamustine }\end{array}$ & $\begin{array}{l}\text { ORR } 81 \% \\
\text { CR } 28 \% \\
20 \text {-month PFS 66\% }\end{array}$ & $\begin{array}{l}\text { ALT/AST elevation I7\% } \\
\text { Pneumonia I5\% } \\
\text { Diarrhea } 8 \%\end{array}$ \\
\hline $\begin{array}{l}\text { Spurgeon } \\
\text { et } \mathrm{al}^{48}\end{array}$ & 1 & $\begin{array}{l}\text { Relapsed } \\
\text { MCL }\end{array}$ & 40 & Alone & $\begin{array}{l}\text { ORR } 40 \% \\
\text { CR } 5 \% \\
\text { Median PFS } 4 \text { months }\end{array}$ & $\begin{array}{l}\text { ALT/AST elevation } 20 \% \\
\text { Diarrhea } 18 \% \\
\text { Pneumonia } 13 \%\end{array}$ \\
\hline $\begin{array}{l}\text { Wagner- } \\
\text { Johnston } \\
\text { et al }{ }^{49}\end{array}$ & $\mathrm{I} / \mathrm{II}$ & $\begin{array}{l}\text { Relapsed } \\
\text { MCL }\end{array}$ & 22 & $\begin{array}{l}\text { In combination with everolimus } \\
(\mathrm{Id}+\mathrm{E}) \text {, bortezomib }(\mathrm{Id}+\mathrm{V}) \text {, } \\
\text { or bendamustine/rituximab } \\
\text { (Id + BR) }\end{array}$ & $\begin{array}{l}\text { ORR } 25 \%(I d+E), \\
50 \%(I d+V), 100 \%(I d+B R) \\
\text { CR 0\% (Id + E, Id + V), } \\
50 \%(I d+B R) \\
\text { Median PFS not reached }\end{array}$ & $\begin{array}{l}\text { Thrombocytopenia } 27 \% \\
\text { Neutropenia } 14 \% \\
\text { Rash I4\% } \\
\text { ALT/AST elevation } 5 \%\end{array}$ \\
\hline $\begin{array}{l}\text { O'Brien } \\
\text { et al }\left.\right|^{50}\end{array}$ & II & $\begin{array}{l}\text { Untreated CLL } \\
>65 \text { years }\end{array}$ & 50 & In combination with rituximab & $\begin{array}{l}\text { ORR } 96 \% \\
\text { CR not reported } \\
\text { 2-year PFS } 91 \%\end{array}$ & $\begin{array}{l}\text { AST/ALT elevation } 22 \% \\
\text { Pneumonia } 20 \% \\
\text { Diarrhea } 16 \%\end{array}$ \\
\hline
\end{tabular}

Abbreviations: CLL, chronic lymphocytic leukemia; CR, complete response; MCL, mantle cell lymphoma; NHL, non-Hodgkin lymphoma; ORR, overall response rate; PFS, progression-free survival; Id, idelalisib; E, everolimus; V, bortezomib; BR, bendamustine/rituximab; ALT, alanine transaminase; AST, aspartate transaminase.

blasts, IC87114 decreases AKT phosphorylation in a dosedependent manner, with maximal PI3K inhibition at $10 \mu \mathrm{M}^{7}$ When compared against a pan-PI3K inhibitor (LY294002), similar reductions in AKT phosphorylation were observed, indicating that $\mathrm{p} 110$-delta is the main contributor to PI3K activity in acute myeloid leukemia blasts. IC87114 was also able to inhibit AKT phosphorylation after FLT3-ligand stimulation. Finally, acute myeloid leukemia blast proliferation was almost completely blocked by IC87114. Furthermore, IC87114 in combination with etoposide has shown synergism in acute myeloid leukemia cell lines by reducing viable cell numbers, which was associated with a reduction in nuclear factor kappa B activity. IC87114 did not appear to enhance the activity of etoposide in terms of proliferation and survival of normal hematopoietic progenitors. ${ }^{22}$ Of note, this molecule has also shown activity against acute promyelocytic leukemia cells in

Table 3 Selected Phase III studies using idelalisib with data reported at the 2013 American Society of Clinical Oncology annual scientific meeting

\begin{tabular}{|c|c|c|c|c|c|}
\hline Author & $\mathbf{n}$ & Disease & Alone/combo & Endpoints & $\begin{array}{l}\text { ClinicalTrials. } \\
\text { Gov ID }\end{array}$ \\
\hline Flinn et $\mathrm{al}^{51}$ & 210 & $\begin{array}{l}\text { Previously } \\
\text { treated CLL }\end{array}$ & $\begin{array}{l}\text { Arm } A \text { idelalisib + ofatumumab } \\
\text { Arm B ofatumumab } \\
\text { Randomization 2:I }\end{array}$ & $\begin{array}{l}\text { Primary, PFS } \\
\text { Secondary, ORR, CR, OS, } \\
\text { lymph node response rate }\end{array}$ & NCT0I65902I \\
\hline Eradat et $\mathrm{al}^{52}$ & 390 & $\begin{array}{l}\text { Previously } \\
\text { treated CLL }\end{array}$ & $\begin{array}{l}\text { Arm A idelalisib + BR } \\
\text { Arm B idelalisib } \\
\text { Randomization I:I }\end{array}$ & $\begin{array}{l}\text { Primary, PFS } \\
\text { Secondary, ORR, CR, OS, } \\
\text { lymph node response rate }\end{array}$ & NCT0I569295 \\
\hline Leonard et $\mathrm{a}^{53}$ & 375 & $\begin{array}{l}\text { Previously } \\
\text { treated } \\
\text { indolent } \mathrm{NHL}\end{array}$ & $\begin{array}{l}\text { Arm A idelalisib + rituximab } \\
\text { Arm B idelalisib } \\
\text { Randomization 2:I }\end{array}$ & $\begin{array}{l}\text { Primary, PFS } \\
\text { Secondary, ORR, CR, OS, } \\
\text { lymph node response rate }\end{array}$ & NCT0I7329I3 \\
\hline De Vos et a $\left.\right|^{54}$ & 450 & $\begin{array}{l}\text { Previously } \\
\text { treated } \\
\text { indolent NHL }\end{array}$ & $\begin{array}{l}\text { Arm A idelalisib + BR } \\
\text { Arm B BR } \\
\text { Randomization 2:1 }\end{array}$ & $\begin{array}{l}\text { Primary, PFS } \\
\text { Secondary, ORR, CR, OS, } \\
\text { lymph node response rate }\end{array}$ & NCT0I732926 \\
\hline
\end{tabular}

Abbreviations: BR, bendamustine and rituximab; CLL, chronic lymphocytic leukemia; CR, complete response; NHL, non-Hodgkin lymphoma; ORR, overall response rate; OS, overall survival; PFS, progression-free survival. 
Table 4 Selected ongoing clinical trials with PI3K inhibitors in hematologic malignancies

\begin{tabular}{|c|c|c|c|c|c|}
\hline ClinicalTrials.Gov ID & Phase & Drug & $\mathbf{n}$ & Disease & Alone/combination \\
\hline NCT0I393I06 & II & Idelalisib & 25 & Hodgkin lymphoma & Alone \\
\hline NCTOI 796470 & II & Idelalisib & 200 & CLL, DLBCL, NHL, MCL & With GS-9973 \\
\hline NCT016936I4 & II & BKMI20 & 66 & DLBCL, FL, MCL & Alone \\
\hline NCT0I882803 & II & IPI- $\mid 45$ & 120 & Refractory indolent NHL & Alone \\
\hline NCT0I306643 & $\mathrm{I} / \mathrm{II}$ & Idelalisib & 15 & Low-grade lymphomas & Alone \\
\hline NCT0I644799 & $1 / I I$ & Idelalisib & 30 & $\mathrm{FL}$ & With lenalidomide and rituximab \\
\hline NCT0I838434 & $1 / I I$ & Idelalisib & 99 & $\mathrm{MCL}$ & With lenalidomide and rituximab \\
\hline NCT0I300026 & 1 & AMG319 & 50 & CLL, lymphoma & Alone \\
\hline NCT0I756II8 & 1 & BEZ235 & 23 & ALL, AML, CML & Alone \\
\hline NCT0I396499 & I & BKMI20 & 16 & Advanced leukemia & Alone \\
\hline NCTOI7I9250 & 1 & BKMI20 & 18 & Relapsed/refractory NHL & Alone \\
\hline NCT0I87I675 & I & IPI- 145 & 70 & CLL, lymphoma & $\begin{array}{l}\text { With bendamustine, rituximab } \\
\text { or bendamustine/rituximab }\end{array}$ \\
\hline NCT0I476657 & I & IPI- 445 & 250 & Advanced hematologic malignancies & Alone \\
\hline
\end{tabular}

Abbreviations: ALL, acute lymphoblastic leukemia; AML, acute myeloid leukemia; CLL, chronic lymphocytic leukemia; CML, chronic myeloid leukemia; DLBCL, diffuse large B-cell lymphoma; FL, follicular lymphoma; MCL, mantle cell lymphoma; NHL, non-Hodgkin lymphoma; PCM, plasma cell myeloma; PI3K, phosphatidylinositol-3-kinase.

a preclinical study. ${ }^{23}$ In acute promyelocytic leukemia, inhibition of p110-beta and p110-delta triggered apoptosis in the presence or absence of all-trans retinoic acid. IC 87114 has also been shown to reverse acute promyelocytic leukemia cells protective mechanisms against doxorubicin or arsenic trioxide, which correlates with downregulation of MCL-1.

\section{PI3K dual inhibitors}

\section{BEZ235}

BEZ235 is a dual inhibitor of PI3K and mTOR with oral bioavailability. ${ }^{24}$ In a preclinical study, this molecule has been shown to induce apoptosis and reduce survival of acute myeloid leukemia cells without significant toxicity to normal CD34+ cells. ${ }^{25}$ BEZ235 has also demonstrated efficacy in plasma cell myeloma cell lines as well as in a murine xenograft model. The $\mathrm{IC}_{50}$ varied depending on which cell lines were tested, but most of the cell lines had an $\mathrm{IC}_{50}$ of $<50 \mathrm{nmol} / \mathrm{L}$. Additionally, three of five patient samples had $\mathrm{IC}_{50}<200 \mathrm{nmol} / \mathrm{L}$. The compound was also tested in peripheral blood mononuclear cells and immortalized hepatocyte cells, and stromal cell survival was not affected at drug levels of $800 \mathrm{nmol} / \mathrm{L}$. When interleukin- 6 and insulin-like growth factor-1 were added to the compound, no survival benefit was conferred to the plasma cell myeloma cell lines. Using a cell viability assay, BEZ235 has also demonstrated an additive effect when combined with dexamethasone, doxorubicin, and bortezomib. ${ }^{26}$ In a recent preclinical study, BEZ235 has been shown to be effective against follicular lymphoma cell lines. ${ }^{27}$ BEZ235 successfully inhibited AKT, mTOR, and S6K phosphorylation in K422, SUDHL16, FL-18, and SUDHL4 cell lines. Inhibition of cell proliferation was due to increased apoptosis characterized by a two-fold increase in caspase 3 activation. In a mouse xenograft model, BEZ235 was associated with minimal toxicity and reduced phosphorylated levels of AKT and S6k, downstream effectors of PI3K and mTOR. Levels of phosphorylated AKT and mTOR were detected in tissue samples from patients with mantle cell lymphoma, facilitating the generation of a bortezomib-resistant mantle cell lymphoma cell line. In this experiment, individual inhibition of PI3K and mTOR showed limited antiproliferative effects; however, dual inhibition with BEZ235 inhibited cell growth. ${ }^{28}$ Ongoing clinical studies are shown in Table 4.

\section{BAG956}

BAG956 is a cell-permeable dual inhibitor of PI3K and PDK1. The $\mathrm{IC}_{50}$ value for the p110-delta subunit is $35 \mathrm{nM}^{29}$ BAG956 is effective against FLT3-mutant acute myeloid leukemia cell lines as well as chronic myeloid leukemia cell lines expressing BCR-ABL. ${ }^{30}$ In both cell lines, BAG956 has been shown to decrease the levels of phosphorylated AKT in a time-dependent manner while no changes were detected in levels of total AKT. Similarly, levels of cyclin D2 decreased with increasing exposure to BAG956. The compound also showed synergy against FLT3-mutant acute myeloid leukemia cells and BCR-ABL chronic myeloid leukemia cells when combined with imatinib, nilotinib, and rapamycin. Given the observed synergy, studies in mice were undertaken. The tumor burden was the lowest in mice treated with the combination of BAG956 and nilotinib or rapamycin than in mice treated with vehicle or either agent alone. 


\section{BGT226}

BGT226 is a dual PI3K and mTOR inhibitor that has been tested in multiple myeloma cell lines as well as samples from patients. It was shown to have an $\mathrm{IC}_{50}$ ranging from 20 to $100 \mathrm{nmol} / \mathrm{L}$ and inhibited cell growth in a time-dependent and dose-dependent manner. In three of four cell lines tested, the compound actually caused apoptosis as opposed to just inhibiting cellular proliferation. BGT226-induced apoptosis is mediated by caspase 3 and characterized by upregulation of BIM, MCL-1, and BAD, and downregulation of BCL-2, BAX, and BCL-XL. ${ }^{31}$ BGT226 induced cell cycle arrest in the G1 phase due to downregulation of cyclin D1 and cyclin D2. The compound was also shown to abrogate the stimulatory effects of interleukin-6, insulin-like growth factor-1, and stromal cell media in multiple myeloma cells. ${ }^{31}$ Similarly, in acute leukemia cells, BGT226 demonstrated strong inhibition of serine and threonine AKT phosphorylation and increased cleavage of caspase 3..$^{32}$ Additionally, cells treated with BGT226 were able to override halting of cell growth and induction of autophagy to induce apoptosis in a cell cycle-independent manner. In this experiment, the apoptotic properties of BGT226 were more pronounced as compared with BEZ235.

\section{$\mathrm{PI}-103$}

PI-103 is a dual inhibitor of PI3K and mTOR. Although this molecule is a more selective inhibitor of the p110-alpha subunit, it still has some inhibitory effect on the p110-delta subunit, with an $\mathrm{IC}_{50}$ of $8 \mathrm{nM}$ and $48 \mathrm{nM}$, respectively. ${ }^{33}$ In acute myeloid leukemia cells, PI-103 resulted in cell cycle arrest in the G1 phase. PI-103 also induced leukemic cell proliferation and induced mitochondrial apoptosis in blast cells, but had little effect on the clonogenic and proliferative properties of normal CD34+ cells. ${ }^{34}$ In chronic lymphocytic leukemia cells, PI-103 has been shown to inhibit chemotaxis and also reduce the spontaneous migration of chronic lymphocytic leukemia cells beneath marrow stromal cells, a process called pseudoemperipolesis. ${ }^{35}$ Additionally, PI-103 appears to induce apoptosis in chronic lymphocytic leukemia cells as well as normal peripheral blood mononuclear cells, although the cytotoxic effect on peripheral blood mononuclear cells is less pronounced than in chronic lymphocytic leukemia cells. This effect seems to be mediated by caspase 7 and poly-(ADP-ribose) polymerase. Finally, PI-103 seemed to sensitize chronic lymphocytic leukemia cells to fludarabine and partially reversed the protective effect of stromal cells on fludarabine-induced apoptosis. In an experiment on primary multiple myeloma cells, $\mathrm{PI}-103$ showed higher activity against cells harboring $\mathrm{t}(4 ; 14)$ and $\mathrm{t}(14 ; 16)$ characterized by increased cyclin D2 activity; however, cells with $t(11 ; 14)$ showing increased cyclin D1 activity showed resistance against PI-103. ${ }^{36}$

\section{IPI- 45}

IPI-145 is a potent oral inhibitor of the PI3K-delta and PI3Kgamma isoforms. IPI-145 was screened against a panel of over 400 diverse kinases using KINOMEscan ${ }^{\circledR}$ technology (DiscoveRx Corporation, Fremont, CA, USA), and was found to selectively bind to PI3K class I isoforms with no significant activity against other protein or lipid kinases, including class II PI3Ks. ${ }^{37}$ In PI3K-gamma-specific and delta-specific assays, IPI-145 inhibited AKT phosphorylation at the nanomolar level, and was shown to be approximately 14 times more potent than idelalisib in terms of delta blockade when compared directly. At the cellular level, IPI-145 inhibited the proliferation of CD19+ B-cells stimulated with anti-IgM and anti-CD40 antibodies. IPI-145 also inhibited the proliferation of CD3+ T-cells stimulated with Concanavalin A.

In a recent Phase I study, 55 patients with relapsed or refractory lymphoma were treated with IPI-145. ${ }^{38}$ Doses $>15 \mathrm{mg}$ twice daily induced complete inhibition of PI3K-delta and increasing suppression of PI3K-gamma with increasing dose. In 36 patients who received $>15 \mathrm{mg}$ twice daily, the most common adverse events were neutropenia and increased alanine aminotransferase. Early clinical activity was seen in T-cell lymphomas, with one complete remission and one partial remission, and B-cell lymphomas, with two complete remissions and nine partial remissions; $90 \%$ of the responses were seen by 3 months of therapy. Ongoing clinical trials are shown in Table 4.

\section{Pan-PI3K inhibitors}

BKM120 inhibits all class I PI3K isoforms with at least 50 -fold selectivity for mTOR and other protein kinases, such as HER1, JAK2, and PDK1. BKM120 has been shown to decrease levels of pAKT in cell lines and xenograft tumor models. In vitro studies have shown that BKM120 exhibits preferential inhibition of tumor cells bearing PI3KCA mutations. ${ }^{39}$ Additional preclinical studies suggest that BKM120 has activity against DLBCL and chronic lymphocytic leukemia lines. In DLBCL, BKM120 induces an increase in the proapoptotic PUMA and BIM and downregulation of the antiapoptotic BCL-XL and MCL- $1 .{ }^{40}$ Similarly, in chronic lymphocytic leukemia primary cells, BKM120 decreased phosphorylation of AKT and FOXO3a, leading to downregulation of MCL-1 and induction of BIM. . $^{41,42}$ BKM120 also inhibited BCR and stroma-dependent AKT 
pathway activation and inhibited cell chemotaxis, sensitizing chronic lymphocytic leukemia cells to bendamustine and fludarabine. ${ }^{42}$ BKM120 has also shown activity against plasma cell myeloma cell lines and primary cells, with limited cytotoxicity in normal lymphocytes. ${ }^{43}$ Additionally, BKM120 prolonged survival of plasma cell myeloma-bearing mice with synergistic effects in combination with dexamethasone. BKM120 causes cell cycle arrest by upregulating p27 and downregulating cyclin D1, and induces apoptosis by downregulating XIAP and inducing BIM. Ongoing clinical trials are shown in Table 4.

\section{Conclusion}

Improvements in the understanding of the PI3K pathway have led to the rational development and use of PI3K inhibitors, mainly in patients with hematologic malignancies. Idelalisib, a p110-delta inhibitor, appears to be the PI3K inhibitor under more advanced development. However, pan-PI3K and dual inhibitors are undergoing development and are already showing promising preclinical and clinical efficacy. The oral bioavailability of such drugs makes them interesting for the management of patients with chronic indolent conditions in whom quality of life might be the main goal of therapy. Our job as clinical researchers is, based on solid preclinical experience, to carefully design and carry out meaningful prospective studies using these compounds alone or in combination to improve responses, quality of life, and ultimately survival.

\section{Disclosure}

The authors report no conflicts of interest in this work.

\section{References}

1. Markman B, Dienstmann R, Tabernero J. Targeting the PI3K/Akt/mTOR pathway - beyond rapalogs. Oncotarget. 2010;1(7):530-543.

2. Reif K, Okkenhaug K, Sasaki T, et al. Cutting edge: differential roles for phosphoinositide 3-kinases, p110gamma and p110delta, in lymphocyte chemotaxis and homing. J Immunol. 2004;173(4):2236-2240.

3. Williams R, Berndt A, Miller S, et al. Form and flexibility in phosphoinositide 3-kinases. Biochem Soc Trans. 2009;37 Pt 4:615-626.

4. Castillo JJ, Furman M, Winer ES. CAL-101: a phosphatidylinositol-3kinase p110-delta inhibitor for the treatment of lymphoid malignancies. Expert Opin Investig Drugs. 2012;21(1):15-22.

5. Chantry D, Vojtek A, Kashishian A, et al. p110delta, a novel phosphatidylinositol 3-kinase catalytic subunit that associates with p85 and is expressed predominantly in leukocytes. J Biol Chem. 1997;272(31): 19236-19241.

6. Herman SE, Gordon AL, Wagner AJ, et al. Phosphatidylinositol 3-kinasedelta inhibitor CAL-101 shows promising preclinical activity in chronic lymphocytic leukemia by antagonizing intrinsic and extrinsic cellular survival signals. Blood. 2010;116(12):2078-2088.

7. Sujobert P, Bardet V, Cornillet-Lefebvre P, et al. Essential role for the p110delta isoform in phosphoinositide 3-kinase activation and cell proliferation in acute myeloid leukemia. Blood. 2005;106(3):1063-1066.
8. Borlado LR, Redondo C, Alvarez B, et al. Increased phosphoinositide 3-kinase activity induces a lymphoproliferative disorder and contributes to tumor generation in vivo. FASEB J. 2000;14(7):895-903.

9. Uddin S, Hussain AR, Siraj AK, et al. Role of phosphatidylinositol 3'-kinase/AKT pathway in diffuse large B-cell lymphoma survival. Blood. 2006;108(13):4178-4186.

10. Hasselblom S, Hansson U, Olsson M, et al. High immunohistochemical expression of $\mathrm{p}$-AKT predicts inferior survival in patients with diffuse large B-cell lymphoma treated with immunochemotherapy. Br J Haematol. 2010;149(4):560-568.

11. Rudelius M, Pittaluga S, Nishizuka S, et al. Constitutive activation of Akt contributes to the pathogenesis and survival of mantle cell lymphoma. Blood. 2006;108(5):1668-1676.

12. Garcia-Martinez JM, Wullschleger S, Preston G, et al. Effect of PI3K- and mTOR-specific inhibitors on spontaneous B-cell follicular lymphomas in PTEN/LKB1-deficient mice. Br J Cancer. 2011;104(7):1116-1125.

13. Renne C, Willenbrock K, Martin-Subero JI, et al. High expression of several tyrosine kinases and activation of the PI3K/AKT pathway in mediastinal large B cell lymphoma reveals further similarities to Hodgkin lymphoma. Leukemia. 2007;21(4):780-787.

14. Ikeda H, Hideshima T, Fulciniti M, et al. PI3K/p110 \{delta $\}$ is a novel therapeutic target in multiple myeloma. Blood. 2010;116(9):1460-1468.

15. Lannutti BJ, Meadows SA, Herman SE, et al. CAL-101, a p110delta selective phosphatidylinositol-3-kinase inhibitor for the treatment of B-cell malignancies, inhibits PI3K signaling and cellular viability. Blood. 2011;117(2):591-594.

16. Hoellenriegel J, Meadows SA, Sivina M, et al. The phosphoinositide 3'-kinase delta inhibitor, CAL-101, inhibits B-cell receptor signaling and chemokine networks in chronic lymphocytic leukemia. Blood. 2011;118(13):3603-3612.

17. Herman SE, Lapalombella R, Gordon AL, et al. The role of phosphatidylinositol 3-kinase-delta in the immunomodulatory effects of lenalidomide in chronic lymphocytic leukemia. Blood. 2011;117(16): 4323-4327.

18. Chanan-Khan AA, Chitta K, Ersing N, et al. Biological effects and clinical significance of lenalidomide-induced tumour flare reaction in patients with chronic lymphocytic leukaemia: in vivo evidence of immune activation and antitumour response. $\mathrm{Br} J$ Haematol. $2011 ; 155(4): 457-467$.

19. Meadows SA, Vega F, Kashishian A, et al. PI3Kdelta inhibitor, GS-1101 (CAL-101), attenuates pathway signaling, induces apoptosis, and overcomes signals from the microenvironment in cellular models of Hodgkin lymphoma. Blood. 2012;119(8):1897-1900.

20. Sinclair A, Metz D, Cushing T, et al. Phosphatidylinositol-3 kinase delta (PI3K $\{$ delta $\}$ ) Inhibitor AMG 319 is a potent, selective and orally bioavailable small molecule inhibitor that suppresses PI3K-mediated signaling and viability in neoplastic B cells. ASH Annual Meeting Abstracts. 2011;118(21):4964.

21. Liu L, Sun B-C, Pistillo J, et al. Phosphatidylinsoitol-3 kinase delta (PI3K $\{$ delta $\}$ ) inhibitor AMG 319 combined with vincristine enhances G2/M arrest and apoptotic death in neoplastic B cells. ASH Annual Meeting Abstracts. 2011;118(21):4963.

22. Billottet C, Grandage VL, Gale RE, et al. A selective inhibitor of the p110delta isoform of PI 3-kinase inhibits AML cell proliferation and survival and increases the cytotoxic effects of VP16. Oncogene. 2006;25(50):6648-6659.

23. Billottet C, Banerjee L, Vanhaesebroeck B, et al. Inhibition of class I phosphoinositide 3-kinase activity impairs proliferation and triggers apoptosis in acute promyelocytic leukemia without affecting atrainduced differentiation. Cancer Res. 2009;69(3):1027-1036.

24. Maira SM, Stauffer F, Brueggen J, et al. Identification and characterization of NVP-BEZ235, a new orally available dual phosphatidylinositol 3-kinase/mammalian target of rapamycin inhibitor with potent in vivo antitumor activity. Mol Cancer Ther. 2008;7(7):1851-1863.

25. Chapuis N, Tamburini J, Green AS, et al. Dual inhibition of PI3K and mTORC1/2 signaling by NVP-BEZ235 as a new therapeutic strategy for acute myeloid leukemia. Clin Cancer Res. 2010;16(22):5424-5435. 
26. McMillin DW, Ooi M, Delmore J, et al. Antimyeloma activity of the orally bioavailable dual phosphatidylinositol 3-kinase/mammalian target of rapamycin inhibitor NVP-BEZ235. Cancer Res. 2009;69(14): 5835-5842.

27. Bhende PM, Park SI, Lim MS, et al. The dual PI3K/mTOR inhibitor, NVP-BEZ235, is efficacious against follicular lymphoma. Leukemia. 2010;24(10):1781-1784.

28. Kim A, Park S, Lee JE, et al. The dual PI3K and mTOR inhibitor NVP-BEZ235 exhibits anti-proliferative activity and overcomes bortezomib resistance in mantle cell lymphoma cells. Leuk Res. 2012;36(7):912-920.

29. Stauffer F, Maira SM, Furet P, et al. Imidazo[4,5-c] quinolines as inhibitors of the PI3K/PKB-pathway. Bioorg Med Chem Lett. 2008;18(3): 1027-1030.

30. Weisberg E, Banerji L, Wright RD, et al. Potentiation of antileukemic therapies by the dual PI3K/PDK-1 inhibitor, BAG956: effects on BCR-ABL- and mutant FLT3-expressing cells. Blood. 2008;111(7): 3723-3734.

31. Baumann P, Schneider L, Mandl-Weber S, et al. Simultaneous targeting of PI3K and mTOR with NVP-BGT226 is highly effective in multiple myeloma. Anticancer Drugs. 2012;23(1):131-138.

32. Kampa-Schittenhelm KM, Heinrich MC, Akmut F, et al. Cell cycledependent activity of the novel dual PI3K-MTORC1/2 inhibitor NVPBGT226 in acute leukemia. Mol Cancer. 2013;12:46.

33. Knight ZA, Gonzalez B, Feldman ME, et al. A pharmacological map of the PI3-K family defines a role for p110alpha in insulin signaling. Cell. 2006;125(4):733-747.

34. Park S, Chapuis N, Bardet V, et al. PI-103, a dual inhibitor of Class IA phosphatidylinositide 3-kinase and mTOR, has antileukemic activity in AML. Leukemia. 2008;22(9):1698-1706.

35. Niedermeier M, Hennessy BT, Knight ZA, et al. Isoform-selective phosphoinositide 3'-kinase inhibitors inhibit CXCR4 signaling and overcome stromal cell-mediated drug resistance in chronic lymphocytic leukemia: a novel therapeutic approach. Blood. 2009;113(22):5549-5557.

36. Glassford J, Kassen D, Quinn J, et al. Inhibition of cell cycle progression by dual phosphatidylinositol-3-kinase and mTOR blockade in cyclin D2 positive multiple myeloma bearing IgH translocations. Blood Cancer J. 2012;2(1):e50

37. Winkler DG, Faia KL, Dinitto JP, et al. PI3K-delta and PI3K-gamma inhibition by IPI-145 abrogates immune responses and suppresses activity in autoimmune and inflammatory disease models. Chem Biol. 2013;20(11):1364-1374.

38. Horwitz SM, Flinn I, Patel MR, et al. Preliminary safety and efficacy of IPI-145, a potent inhibitor of phosphoinositide-3-kinase\{delta $\},\{$ gamma $\}$, in patients with relapsed/refractory lymphoma. ASCO Meeting Abstracts. 2013;31(Suppl 15):8518.

39. Maira SM, Pecchi S, Huang A, et al. Identification and characterization of NVP-BKM120, an orally available pan-class I PI3-kinase inhibitor. Mol Cancer Ther. 2012;11(2):317-328.

40. Zang C, Eucker J, Liu H, et al. Inhibition of pan-class I phosphatidylinositol-3-kinase by NVP-BKM120 effectively blocks proliferation and induces cell death in diffuse large B-cell lymphoma. Leuk Lymphoma. July 25, 2013. [Epub ahead of print.]

41. Amrein L, Shawi M, Grenier J, et al. The phosphatidylinositol-3 kinase I inhibitor BKM120 induces cell death in B-chronic lymphocytic leukemia cells in vitro. Int J Cancer. 2013;133(1):247-252.

42. Rosich L, Saborit-Villarroya I, Lopez-Guerra M, et al. The phosphatidylinositol-3-kinase inhibitor NVP-BKM120 overcomes resistance signals derived from microenvironment by regulating the $\mathrm{Akt} / \mathrm{FoxO} 3 \mathrm{a} /$ Bim axis in chronic lymphocytic leukemia cells. Haematologica. 2013;98(11):1739-1747.
43. Zheng Y, Yang J, Qian J, et al. Novel phosphatidylinositol 3-kinase inhibitor NVP-BKM120 induces apoptosis in myeloma cells and shows synergistic anti-myeloma activity with dexamethasone. $\mathrm{J} \mathrm{Mol} \mathrm{Med}$ (Berl). 2012;90(6):695-706.

44. Brown JR, Furman RR, Flinn I, et al. Final results of a phase I study of idelalisib (GSE1101) a selective inhibitor of PI3K \{delta\}, in patients with relapsed or refractory CLL. ASCO Meeting Abstracts. 2013; 31(Suppl 15):7003.

45. Barrientos JC, Furman RR, Leonard J, et al. Update on a phase I study of the selective PI3K \{delta $\}$ inhibitor idelalisib (GS-1101) in combination with rituximab and/or bendamustine in patients with relapsed or refractory CLL. ASCO Meeting Abstracts. 2013;31(Suppl 15):7017.

46. Benson DM, Kahl BS, Furman RR, et al. Final results of a phase I study of idelalisib, a selective inhibitor of PI $3 \mathrm{~K}\{$ delta $\}$, in patients with relapsed or refractory indolent non-Hodgkin lymphoma (iNHL). ASCO Meeting Abstracts. 2013;31(Suppl 15):8526.

47. Leonard J, Wagner-Johnston ND, Coutre SE, et al. Tolerability and activity of combinations of the PI $3 \mathrm{~K}$ \{delta $\}$ inhibitor idelalisib (GS-1101) with rituximab and/or bendamustine in patients with previously treated, indolent non-Hodgkin lymphoma (iNHL): updated results from a phase I study. ASCO Meeting Abstracts. 2013;31(Suppl 15): 8500 .

48. Spurgeon SEF, Wagner-Johnston ND, Furman RR, et al. Final results of a phase I study of idelalisib, a selective inhibitor of phosphatidylinositol 3-kinase P110 delta $\}$ (PI3K $\{$ delta $\}$ ), in patients with relapsed or refractory mantle cell lymphoma (MCL). ASCO Meeting Abstracts. 2013; 31(Supp1 15):8519.

49. Wagner-Johnston ND, De Vos S, Leonard J, et al. Preliminary results of PI3K $\{$ delta $\}$ inhibitor idelalisib (GS-1101) treatment in combination with everolimus, bortezomib, or bendamustine/rituximab in patients with previously treated mantle cell lymphoma (MCL). ASCO Meeting Abstracts. 2013;31(Suppl 15):8501.

50. O’Brien SM, Lamanna N, Kipps TJ, et al. A phase II study of the selective phosphatidylinositol 3-kinase delta (PI3K \{delta $\}$ ) inhibitor idelalisib (GS-1101) in combination with rituximab (R) in treatment-naive patients (pts) $\geq 65$ years with chronic lymphocytic leukemia (CLL) or small lymphocytic lymphoma (SLL). ASCO Meeting Abstracts. 2013;31(Suppl 15):7005.

51. Flinn I, Kimby E, Cotter FE, et al. A phase III, randomized, controlled study evaluating the efficacy and safety of idelalisib (GS-1101) in combination with ofatumumab for previously treated chronic lymphocytic leukemia (CLL). ASCO Meeting Abstracts. 2013;31(Suppl 15): TPS7131.

52. Eradat HA, Coutre SE, Barrientos JC, et al. A phase III, randomized, double-blind, placebo-controlled study evaluating the efficacy and safety of idelalisib (GS-1101) in combination with bendamustine and rituximab for previously treated chronic lymphocytic leukemia (CLL). ASCO Meeting Abstracts. 2013;31(Suppl 15):TPS7133.

53. Leonard J, Zinzani PL, Jurczak W, et al. A phase III, randomized, double-blind, placebo-controlled study evaluating the efficacy and safety of idelalisib (GS-1101) in combination with rituximab for previously treated indolent non-Hodgkin lymphomas (iNHL). ASCO Meeting Abstracts. 2013;31(Suppl 15):TPS8617.

54. De Vos S, Sehn LH, Mulligan SP, et al. A phase III, randomized, double-blind, placebo-controlled study evaluating the efficacy and safety of idelalisib (GS-1101) in combination with bendamustine and rituximab for previously treated indolent non-Hodgkin lymphomas (iNHL). ASCO Meeting Abstracts. 2013;31(Suppl 15):TPS8618. 


\section{Publish your work in this journal}

OncoTargets and Therapy is an international, peer-reviewed, open access journal focusing on the pathological basis of all cancers, potential targets for therapy and treatment protocols employed to improve the management of cancer patients. The journal also focuses on the impact of management programs and new therapeutic agents and protocols on patient perspectives such as quality of life, adherence and satisfaction. The manuscript management system is completely online and includes a very quick and fair peer-review system, which is all easy to use. Visit http://www.dovepress.com/testimonials.php to read real quotes from published authors.

Submit your manuscript here: http://www.dovepress.com/oncotargets-and-therapy-journal 